\title{
Radiosensitizing effects of arsenic trioxide on MCF-7 human breast cancer cells exposed to ${ }^{89}$ strontium chloride
}

\author{
HENGCHAO LIU ${ }^{1,2}$, XINQUAN TAO ${ }^{1}$, FANG MA $^{3}$, JUN QIU $^{2}$, CUIPING WU ${ }^{2}$ and MINGMING WANG ${ }^{2}$ \\ ${ }^{1}$ Department of Nuclear Medicine, First Affiliated Hospital, Bengbu Medical College, Bengbu, Anhui 233004; \\ ${ }^{2}$ Institute of Radiation Medicine, School of Clinical Medicine, Anhui Medical University, Hefei, Anhui 230601; \\ ${ }^{3}$ Department of Medical Laboratory, Bengbu Medical College, Bengbu, Anhui 233030, P.R. China
}

Received April 30, 2012; Accepted June 19, 2012

DOI: $10.3892 /$ or.2012.1979

\begin{abstract}
The aim of this study was to investigate the radiosensitizing effects of arsenic trioxide $\left(\mathrm{As}_{2} \mathrm{O}_{3}\right)$ on MCF-7 human breast cancer cells irradiated with ${ }^{89}$ strontium chloride $\left({ }^{89} \mathrm{SrCl}_{2}\right)$. The $50 \%$ inhibitory concentration $\left(\mathrm{IC}_{50}\right)$ was calculated from results of an MTT assay. The concentration of $\mathrm{As}_{2} \mathrm{O}_{3}$ less than $20 \% \mathrm{IC}_{50}$ was selected for subsequent experiments. Cells were treated with $\mathrm{As}_{2} \mathrm{O}_{3}$ and ${ }^{89} \mathrm{SrCl}_{2}$. Morphological changes of cells were observed under an inverted microscope. The radiosensitivity enhancing ratio (SER) was computed based on a clone formation assay. Cell cycle distribution and apoptosis were measured by flow cytometry (FCM). Expression of Bcl-2 and Bax at both the mRNA and protein levels was assessed by RT-PCR and western blotting. The $\mathrm{IC}_{50}$ of $\mathrm{As}_{2} \mathrm{O}_{3}$ at $24 \mathrm{~h}$ was $11.7 \mu \mathrm{M}$. Doses of $\mathrm{As}_{2} \mathrm{O}_{3}(1$ and $2 \mu \mathrm{M})$ were used in combination treatments and SER values were 1.25 and 1.79 , respectively. $\mathrm{As}_{2} \mathrm{O}_{3}$ significantly suppressed cell growth, caused $\mathrm{G}_{2} / \mathrm{M}$ arrest, enhanced cell death and apoptosis induced by ${ }^{89} \mathrm{SrCl}_{2}$ and decreased expression of the Bcl-2 gene. Since expression of Bax was unchanged following treatment, $\mathrm{As}_{2} \mathrm{O}_{3}$ effectively reduced the $\mathrm{Bcl}-2 / \mathrm{Bax}$ ratio. $\mathrm{As}_{2} \mathrm{O}_{3}(1-2 \mu \mathrm{M})$ enhances the cytotoxic effects of ${ }^{89} \mathrm{SrCl}_{2}$ on the MCF-7 human breast cancer cell line by inducing $\mathrm{G}_{2}$ phase delay and promoting apoptosis through the reduction of the $\mathrm{Bcl}-2 / \mathrm{Bax}$ ratio.
\end{abstract}

\section{Introduction}

Breast cancer is one of the most common types of cancer in women and accounts for 7-10\% of all diseases. Approximately 40 million people succumb to the disease each year (1). The incidence of breast cancer is rising in China (2) and is threatening to become a severe public health problem. Of patients with breast cancer $60-80 \%$ will develop bone metastases during the course of the disease (3). More than half of these

Correspondence to: Dr Mingming Wang, Institute of Radiation Medicine, School of Clinical Medicine, Anhui Medical University, No.15 Feicui Road, Hefei, Anhui 230601, P.R. China

E-mail:wmgene@163.com

Key words: arsenic trioxide, breast cancer $\mathrm{MCF}-7$ cell line, ${ }^{89}$ strontium chloride, radiosensitizer, Bcl-2 gene, Bax gene patients will experience persistent and increasing bone pain, which seriously impairs the patient's quality of life.

Radiation therapy is a common option for the treatment of breast cancer. Such therapeutic options include external beam radiation therapy and internal radionuclide therapy. In most breast cancer patients with bone metastases, pain in the bone can be relieved through radiation therapy. However, the benefits of radiation therapy can be limited by damage repair mechanisms, cell repopulation, and radiation-resistant hypoxic tumor cells. The radiosensitivity of tumor cells is an important factor that affects the efficacy of radiotherapy. In 1963, Adams et al (4) used nitroacetophenone to radiosensitize rat hypoxic cells. Following this initial report, many researchers have been developing radiation-sensitizing drugs to improve the efficacy of radiotherapy.

Radiation sensitizing agents are defined as any chemicals or biological reagents that selectively enhance the lethality of radiation on tumor cells or that reduce the radiation resistance of tumor cells. Thus, they improve the effect of radiation therapy. The ideal radiation sensitizer should meet the following criteria (5): (i) the agent should be stable and should not easily react with other substances; (ii) the effective dose should not be toxic or at least tolerable; (iii) the agent should be soluble in water for easy delivery; (iv) even at low doses, the drug should have radiation sensitizing effects in conventional fractionated treatment. However, it is difficult to find radiation sensitizers that fully meet all these criteria. In practice, drugs that enhance radiotherapy and show limited toxicity are often used as radiation sensitizers.

Chemotherapy drugs are the best studied agents for promoting radiosensitivity. However, chemotherapeutic drugs are toxic to normal cells and can have synergistic effects with radiation, often making them intolerable for patients. Therefore, there is still a clear need for novel radiation sensitizers in the clinic.

Arsenic trioxide $\left(\mathrm{As}_{2} \mathrm{O}_{3}\right)$ was first used for the treatment of acute promyelocytic leukemia (APL) in 1970, and it was approved by the U.S. Federal Food and Drug Administration (FDA) in 2000. Previous studies (6-8) found that, in addition to APL, $\mathrm{As}_{2} \mathrm{O}_{3}$ is also effective against a number of solid tumors, including esophageal, liver, breast and gastric cancer. Although high doses of $\mathrm{As}_{2} \mathrm{O}_{3}$ may show significant toxicity, low doses can have notable antitumor effects, including changing tumor 
cell cycle distribution, promoting cell differentiation and apoptosis, reducing glutathione levels, directly damaging DNA, and inhibiting tumor angiogenesis (9-12). It is possible that $\mathrm{As}_{2} \mathrm{O}_{3}$ may also have radiosensitizing effects. In the present study, we examined whether $\mathrm{As}_{2} \mathrm{O}_{3}$ could sensitize human MCF-7 breast cancer cells to ${ }^{89} \mathrm{SrCl}_{2} \beta$-ray irradiation in vitro and we also investigated the underlying molecular mechanisms.

\section{Materials and methods}

Cell line. Human breast cancer MCF-7 cell line was obtained from the experimental center of clinical laboratory diagnostics at Bengbu Medical College. They were cultured in RPMI-1640 medium (Gibco, CA, USA) supplemented with 10\% FBS (Gibco) in an incubator with $5 \% \mathrm{CO}_{2}$ and saturated humidity at $37^{\circ} \mathrm{C}$.

MTT assay evaluation of the effects of $\mathrm{As}_{2} \mathrm{O}_{3}$ on cell proliferation. MCF-7 cells $\left(1.0 \times 10^{4}\right.$ cells per well) were seeded in 96-well plates and cultured for $24 \mathrm{~h}$. The medium was then replaced with the same medium containing $\mathrm{As}_{2} \mathrm{O}_{3}$ (Sigma, MO, USA) at concentrations of $0,0.5,1,2,5,10,20,50$ and $100 \mu \mathrm{M}$ for $24 \mathrm{~h}$ (6 wells at each concentration). Following incubation, the medium was removed and $200 \mu \mathrm{l}$ of fresh medium containing $50 \mu \mathrm{g} / \mu \mathrm{l}$ MTT (Sigma) was added into each well and incubated for an additional $4 \mathrm{~h}$. Medium was then discarded and $150 \mu \mathrm{l}$ dimethyl sulfoxide (DMSO, Sigma) was added. Optical density (OD) at $570 \mathrm{~nm}$ was measured by DG3022A type Microplate Reader (State-run East China Electronic Tube Factory). The rate of cell proliferation was calculated as follows: (experimental OD value/control OD value) $x 100 \%$. The experiment was repeated 6 times. Growth curves were plotted; the ordinate and abscissa represent the concentration of $\mathrm{As}_{2} \mathrm{O}_{3}$ and the rate of cell proliferation, respectively. According to the curve, the 50\% inhibiting concentration $\left(\mathrm{IC}_{50}\right)$ was calculated.

${ }^{89} \mathrm{SrCl}_{2}$ irradiation and the calculation of absorbed dose. Cells were cultured for $24 \mathrm{~h}$, medium was removed, and fresh medium containing 740,1480 or $2960 \mathrm{kBq} / \mathrm{ml}$ of ${ }^{89} \mathrm{SrCl}_{2}$ (Chengdu Gaotong Isotope Co., Ltd.) was added to the wells for another $48 \mathrm{~h}$. Cumulative absorbed doses from ${ }^{89} \mathrm{Sr}$ internal irradiation were computed according to the formulation (13), $\mathrm{D}=\mathrm{AEt} / \mathrm{m}$ (where $\mathrm{A}, \mathrm{E}, \mathrm{m}$ and $\mathrm{t}$ represent radioactivity of ${ }^{89} \mathrm{SrCl}_{2}$, mean energy of $\beta$-ray from ${ }^{89} \mathrm{Sr}$, mass of irradiated cells and irradiating time, respectively).

Cell grouping and treatment. MCF-7 $\left(5 \times 10^{4}\right)$ cells per well were seeded in 6-well plates and incubated for $24 \mathrm{~h}$. Cells were then randomly divided into four groups: control, $\mathrm{As}_{2} \mathrm{O}_{3},{ }^{89} \mathrm{SrCl}_{2}$ and $\mathrm{As}_{2} \mathrm{O}_{3}+{ }^{89} \mathrm{SrCl}_{2}$ group (combination group). Each treatment was performed in triplicate. The $\mathrm{As}_{2} \mathrm{O}_{3}$ and the combination group were treated with 1 or $2 \mu \mathrm{mol} / 1$ of $\mathrm{As}_{2} \mathrm{O}_{3}$ for $24 \mathrm{~h} .{ }^{89} \mathrm{SrCl}_{2}$ was added into both the ${ }^{89} \mathrm{SrCl}_{2}$ and the combination group for another $48 \mathrm{~h}$. Medium was then removed and fresh medium was added into each well. Cells were cultured for another $24 \mathrm{~h}$. The experiment was repeated 6 times.

Morphological observations. The morphological changes of MCF-7 cells in each group were observed under an inverted microscope and images were captured with a digital camera.
Colony formation assay to detect the effects of ${ }^{89} \mathrm{SrCl}_{2}$ on cell proliferation. Cells were detached from culture dishes with $0.25 \%$ trypsin (Sigma) and adjusted to $5 \times 10^{4} / \mathrm{ml}$ with fresh medium. Various treatments, including 0, 370, 740, 1480, 2960,4440 and $5920 \mathrm{kBq} / \mathrm{ml}$ of ${ }^{89} \mathrm{SrCl}_{2}$ were added to 100 , 150, 200, 400, 1000, 2000 and 10000 cells. Cells were seeded in triplicate in different wells of 6-well plates for $24 \mathrm{~h}$. Cells in the $\mathrm{As}_{2} \mathrm{O}_{3}$ group and the combination group were treated with 1 or $2 \mu \mathrm{M}$ of $\mathrm{As}_{2} \mathrm{O}_{3}$ for $24 \mathrm{~h} .{ }^{89} \mathrm{SrCl}_{2}$ was added into the ${ }^{89} \mathrm{SrCl}_{2}$ group and the combination group for another $48 \mathrm{~h}$. Medium was then discarded and fresh medium was added into each well. Cells were cultured for a total of 12 days. Subsequently, cells were rinsed with phosphate-buffered saline (PBS), and colonies were fixed with $95 \%$ ethanol for $15 \mathrm{~min}$. They were then stained with crystal violet for $20 \mathrm{~min}$ and counted under the microscope. Survival fraction, $\mathrm{SF}=$ no. of colonies formed/(no. of cells seeded x plating efficiency of the control). The cell survival curve was plotted by the multi-target one hit model (14). Mean lethal dose $\left(D_{0}\right)$, quasi-threshold dose $\left(D_{q}\right)$, extrapolation number $(\mathrm{N})$ and radiosensitivity enhancing ratio (SER) were calculated.

Cell cycle analysis. Cells were harvested and rinsed with PBS. They were fixed with $70 \%$ ethanol at $4^{\circ} \mathrm{C}$ overnight. The following day, cells were centrifuged and the supernatant was discarded. Pellets were rinsed twice with PBS and incubated with $1.5 \mu 125 \mathrm{mg} / \mathrm{ml} \mathrm{RNase} \mathrm{A}$ (Sigma) at $37^{\circ} \mathrm{C}$ for $30 \mathrm{~min}$. They were then stained with $12 \mu \mathrm{l} 50 \mu \mathrm{g} / \mathrm{ml} \mathrm{PI}$ and protected from light at $4^{\circ} \mathrm{C}$ for $30 \mathrm{~min}$. Cell cycle distribution was measured by FACSCalibur type flow cytometer (Becton-Dickinson).

Cell apoptosis analysis. Buffer was prepared according to instructions provided for the Annexin V-FITC/PI apoptosis detection kit (BD Biosciences, USA). Cells were harvested, mixed with $300 \mu \mathrm{l}$ buffer, incubated in the dark with $5 \mu \mathrm{l}$ Annexin V-FITC for $15 \mathrm{~min}$, and then mixed with $5 \mu \mathrm{l}$ PI for 5 min. Cell apoptosis was analyzed by flow cytometry (FCM).

Expression of Bcl-2 and Bax mRNA measured by RT-PCR. Total RNA was isolated with TRIzol reagent (Invitrogen, CA, USA) according to the manufacturer's instructions. cDNA was synthesized at $42^{\circ} \mathrm{C}$ for $1 \mathrm{~h}$ and at $70^{\circ} \mathrm{C}$ for $10 \mathrm{~min}$ from $4 \mu \mathrm{g}$ of total RNA using the SuperScript II Reverse Transcriptase (Invitrogen) following the manufacturer's protocol. cDNA was subsequently amplified using Hot-StarTaq DNA Polymerase (Qiagen, Australia) and primers at MyCycler ${ }^{\mathrm{TM}}$ type PCR (Bio-Rad, CA, USA). Sequences of the primers are as follows (Shanghai Sangon Biological Engineering Technology and Services Co., Ltd.): GAPDH: 5'-GGGAAGGTGAAGGTCGGAGTC-3' (sense primer), 5'-AGCAGAGGGGGCAGAGATGAT-3' (antisense primer); Bcl-2: 5'-CAGCTGCACCTGACGCCCTT-3' (sense primer), 5'-GCCTCCGTTATCCTGGATCC-3' (antisense primer); Bax: 5'-ACCAAGAAGCTGAGCGAGTGTC-3' (sense primer), 5'-TGTCCAGCCCATGATGGTTC-3' (antisense primer).

The PCR program consisted of initial denaturation at $95^{\circ} \mathrm{C}$ for $3 \mathrm{~min}$, followed by 30 cycles of denaturation at $95^{\circ} \mathrm{C}$ for $45 \mathrm{sec}$, annealing for $45 \mathrm{sec}$ at $55^{\circ} \mathrm{C}(\mathrm{Bcl}-2), 58^{\circ} \mathrm{C}(\mathrm{Bax})$ or $63^{\circ} \mathrm{C}(\mathrm{GAPDH})$ and extension at $72^{\circ} \mathrm{C}$ for $1 \mathrm{~min}$. A final extension step at $72^{\circ} \mathrm{C}$ for 10 min was included for all primers. PCR 
products were stored at $4^{\circ} \mathrm{C}$ and electrophoresed in agarose gel buffered by $1 \mathrm{X}$ TBE at $100 \mathrm{~V}$. Images were captured with an ultraviolet analyzer. The electrophoretic pattern was semi-quantitatively analyzed with SmartView image software, and the ratio of sample intensity to intensity of GAPDH was determined.

Western blot analysis. Protein was extracted from cultured cells and subjected to western blot analysis using specific antibodies to $\mathrm{Bcl}-2$ and $\mathrm{Bax}$. The cells were harvested and rinsed with PBS. Cell extracts were prepared with pre-chilled lysis buffer $(50 \mathrm{mM}$ Tris-HCl, $150 \mathrm{mM} \mathrm{NaCl}, 1 \%$ Triton X-100, $0.5 \%$ deoxycholate, $1 \mathrm{mM}$ EDTA, $1 \mathrm{mM} \mathrm{Na} \mathrm{VO}_{4}, 1 \mathrm{mM} \mathrm{NaF}$, $2 \%$ Cocktail) and cleared by centrifugation at $12,000 \mathrm{~g}$ for $30 \mathrm{~min}$ at $4^{\circ} \mathrm{C}$. The supernatant was collected and total protein concentration was measured using the BCA assay kit (Sigma) according to the manufacturer's instructions. Cellular extract containing $30 \mu \mathrm{g}$ of total protein was separated by $12 \%$ sodium dodecylbenzene sulfonate-polyacrylamide gel electrophoresis (SDS-PAGE), and the protein was transferred to PVDF membrane (Millipore, MA, USA). The membrane was then blocked with TBST (10 mM Tris-HCl, pH 7.4, $150 \mathrm{mM} \mathrm{NaCl}$, $0.1 \%$ Tween-20) containing $5 \% \mathrm{w} / \mathrm{v}$ non-fat dry milk at $37^{\circ} \mathrm{C}$ for $1 \mathrm{~h}$. It was then incubated with mouse anti-human Bcl-2 or Bax antibodies (1:200; Santa Cruz Biotechnology, CA, USA) or $\beta$-actin antibody (1:800; Santa Cruz Biotechnology) in TBST at $4^{\circ} \mathrm{C}$ overnight. The membrane was washed three times and hybridized with horseradish peroxidase-conjugated sheep anti-mouse $\operatorname{IgG}(1: 2000$; Millipore) for $2 \mathrm{~h}$ at room temperature. After washing three times for $10 \mathrm{~min}$ each with $15 \mathrm{ml}$ TBST, protein bands specific for the antibodies were visualized by enhanced chemiluminescence (Amersham Pharmacia Biotech, NJ, USA) associated with fluorography. The intensity of bands for Bcl-2 and Bax proteins were analyzed with Smart view image software and the relative values of $\mathrm{Bcl}-2 / \mathrm{Bax}$ in different groups were calculated.

Statistics. Data are presented as the mean \pm SD. Differences between two groups were determined by a t-test between independent samples using SPSS 11.5 software. The relationship between cell viability and $\mathrm{As}_{2} \mathrm{O}_{3}$ concentration was assayed using curvilinear regression and correlation analysis.

\section{Results}

Suppression of MCF-7 cell proliferation by $\mathrm{As}_{2} \mathrm{O}_{3}$. We measured MCF-7 cell proliferation $24 \mathrm{~h}$ after treatment with multiple concentrations of $\mathrm{As}_{2} \mathrm{O}_{3}$ and found that the proliferation of cells was suppressed to varying degrees (Fig. 1). $\mathrm{As}_{2} \mathrm{O}_{3}$ doses below $2 \mu \mathrm{M}$ slightly inhibited (reduced by only $20 \%$ ) cell proliferation; at $\mathrm{As}_{2} \mathrm{O}_{3}$ concentrations above $5 \mu \mathrm{M}$, proliferation was much more significantly inhibited. Markedly, the degree of inhibition increased in a dose-dependent manner. The curvilinear regression equation $\mathrm{Y}=91.7 \mathrm{C}^{-0.225}\left(\mathrm{r}^{2}=0.983\right.$, $\mathrm{P}<0.05)$ between the percentage of cell proliferation ( $\mathrm{Y}, \%)$ and $\mathrm{As}_{2} \mathrm{O}_{3}$ concentration $(\mathrm{C}, \mu \mathrm{M})$ was plotted, and the $\mathrm{IC}_{50}$ at $24 \mathrm{~h}$ was calculated to be $11.7 \mu \mathrm{M}$. To prevent the killing of MCF-7 cells by $\mathrm{As}_{2} \mathrm{O}_{3}$, only 1 and $2 \mu \mathrm{M}$ doses of compound were used to investigate the radiosensitizing effects of $\mathrm{As}_{2} \mathrm{O}_{3}$ on cells treated with ${ }^{89} \mathrm{SrCl}_{2}$.

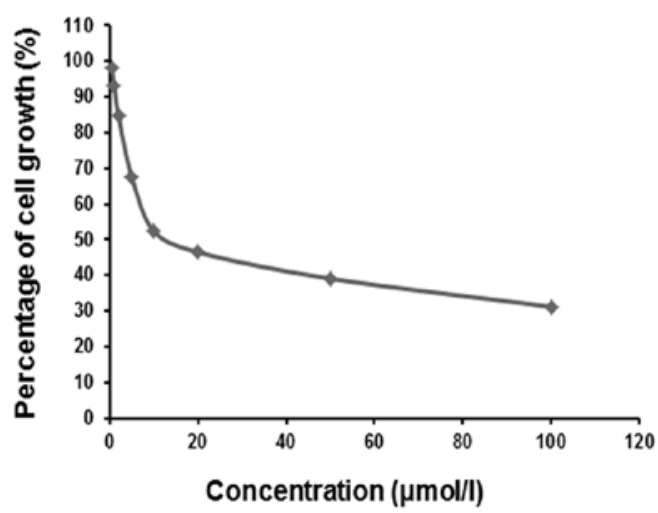

Figure 1. Growth curve of MCF-7 cells treated with $\mathrm{As}_{2} \mathrm{O}_{3}$.

Cumulative absorbed dose of MCF-7 cells exposed to ${ }^{89} \mathrm{SrCl}_{2}$. MCF-7 cells were exposed for $48 \mathrm{~h}$ to $370,740,1480,2960$, 4440 and $5920 \mathrm{kBq} / \mathrm{ml}$ of ${ }^{89} \mathrm{SrCl}_{2}$. Cumulative absorbed doses of ${ }^{89} \mathrm{SrCl}_{2}$ were $0.5,1,2,4,6$ and $8 \mathrm{~Gy}$, respectively.

Morphological changes of MCF-7 cells treated with $\mathrm{As}_{2} \mathrm{O}_{3}$ and ${ }^{89} \mathrm{SrCl}_{2}$. MCF-7 cells were observed under an inverted microscope. Cells in the control group were adhered to the culture dish and grew normally. They displayed a typical polygon or spindle shape, clear cell profile, and intact nuclei. However, cells in the $\mathrm{As}_{2} \mathrm{O}_{3}$ group experienced morphological changes, including partly condensed chromatin and the appearance of vacuoles. Morphological changes of cells in the ${ }^{89} \mathrm{SrCl}_{2}$ group were also apparent. With the increase of ${ }^{89} \mathrm{SrCl}_{2}$ concentration, cells gradually became round and unattached. They showed decreased refractive indexes, increased particles in crystal, vacuole-like structures and partly ruptured nuclear membranes. Additionally, debris appeared around cells, some dead cells were found floating in the medium, soma became round in shape, the chromatin condensed and karyopyknosis and fragmentation occurred. The proliferation of cells in the combination group was significantly suppressed, with increased cell debris, incomplete nuclear membranes and smaller shapes and sizes (Fig. 2).

Clone formation assay evaluating the radiosensitizing effects of $\mathrm{As}_{2} \mathrm{O}_{3}$ on MCF-7 cells treated with ${ }^{89} \mathrm{SrCl}_{2}$. MCF-7 cell survival curves in different groups are shown in Fig. 3. Curve equations were as follows: ${ }^{89} \mathrm{SrCl}_{2}$ group, $\mathrm{SF}_{1}=1-\left(1-\mathrm{e}^{-\mathrm{D} / 2.89}\right)^{2.18}$; $1 \mu \mathrm{M} \mathrm{As} \mathrm{O}_{3}+{ }^{89} \mathrm{SrCl}_{2}$ group, $\mathrm{SF}_{2}=1-\left(1-\mathrm{e}^{-\mathrm{D} / 2.32}\right)^{\mathbf{2 . 1 0}} ; 2 \mu \mathrm{M}$ $\mathrm{As}_{2} \mathrm{O}_{3}+{ }^{89} \mathrm{SrCl}_{2}$ group, $\mathrm{SF}_{3}=1-\left(1-\mathrm{e}^{-\mathrm{D} / 1.61}\right)^{1.95}$. For the formulas, $\mathrm{SF}$ represents cell survival rate and $\mathrm{D}$ is irradiated dose. The shoulder zone of the cell survival curve in the combination group became narrow, with an increased slope of the linear part, reduced mean lethal dose $\left(\mathrm{D}_{0}\right)$ and quasi-threshold dose $\left(\mathrm{D}_{\mathrm{q}}\right)$ (compared with those in the ${ }^{89} \mathrm{SrCl}_{2}$ group, $\mathrm{P}<0.05$ ). It showed that $\mathrm{As}_{2} \mathrm{O}_{3}$ may radiosensitize MCF-7 cells exposed to $\beta$-rays from ${ }^{89} \mathrm{SrCl}_{2}$. Radiosensitization effects were enhanced with increased $\mathrm{As}_{2} \mathrm{O}_{3}$ concentrations in the low level range. Clones are shown in Fig. 4.

Effects of $\mathrm{As}_{2} \mathrm{O}_{3}$ and ${ }^{89} \mathrm{SrCl}_{2}$ on the distribution of MCF-7 cell cycle. Cells in the control group were found mostly in 

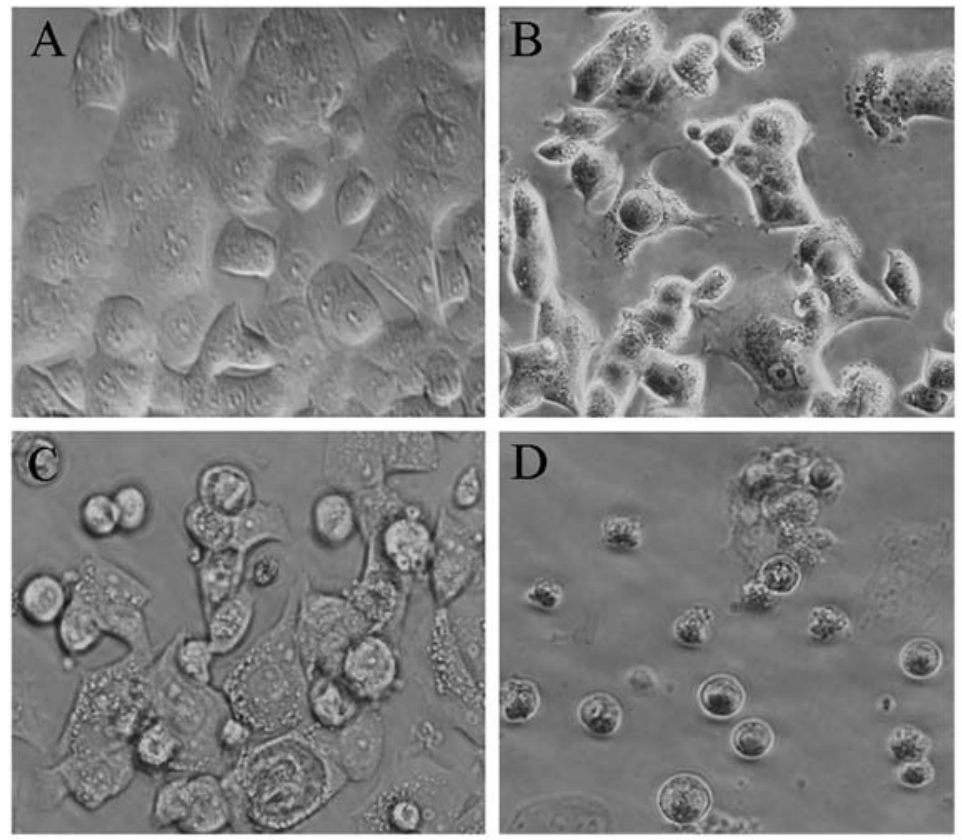

Figure 2. Morphological changes of MCF-7 cells in different groups (20x10). (A) Control. (B) $2 \mu \mathrm{M} \mathrm{As}_{2} \mathrm{O}_{3}$ group. (C) $4 \mathrm{~Gy}{ }^{89} \mathrm{SrCl}_{2}$ group. (D) Combination group.

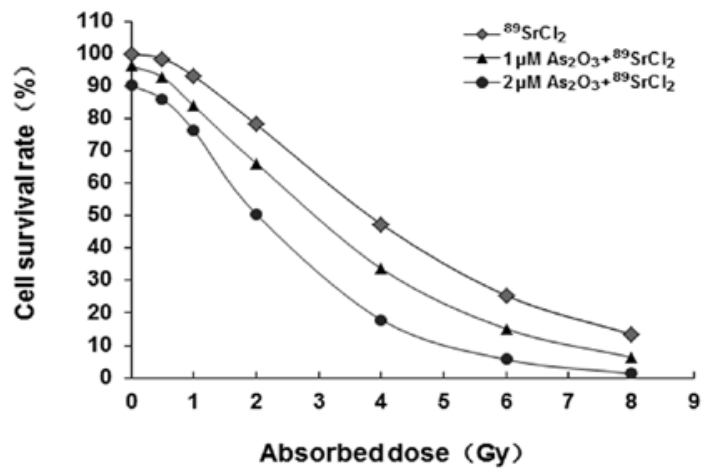

Figure 3. MCF-7 cell survival curves in different groups.

phases $\mathrm{G}_{0} / \mathrm{G}_{1}$ or $\mathrm{S}$ of the cell cycle. Cells in the treatment groups were mostly found to be in the $\mathrm{G}_{2} / \mathrm{M}$ phase. In both the $\mathrm{As}_{2} \mathrm{O}_{3}$-treated and ${ }^{89} \mathrm{SrCl}_{2}$-treated groups, the percentage of cells in $\mathrm{G}_{2} / \mathrm{M}$ phase increased in a dose-dependent manner (compared with control, $\mathrm{P}<0.05$ ). The percentage of cells in $\mathrm{G}_{2} / \mathrm{M}$ phase in the combination group increased dramatically. This increase was most apparent in the $2 \mu \mathrm{M} \mathrm{As}_{2} \mathrm{O}_{3}$ and $4 \mathrm{~Gy}$ ${ }^{89} \mathrm{SrCl}_{2}$ group; $45.8 \%$ of the cell population was in $\mathrm{G}_{2} / \mathrm{M}$. Of note, cells in $\mathrm{S}$ phase decreased compared with those in the ${ }^{89} \mathrm{SrCl}_{2}$ group $(\mathrm{P}<0.05)$ (Table I).

Effects of $\mathrm{As}_{2} \mathrm{O}_{3}$ and ${ }^{89} \mathrm{SrCl}_{2}$ on $\mathrm{MCF}-7$ cell apoptosis. Annexin V-FITC/PI double staining flow cytometry was used to discriminate among live cells, dead cells, and cells during early or late apoptotis (Fig. 5). Cells were divided into four subpopulations: live cells with low levels of Annexin V and PI (LL zone), cells in the early apoptotic phase with high levels of Annexin V and low levels of PI (LR zone), cells in the late apoptotic phase, and dead cells with high

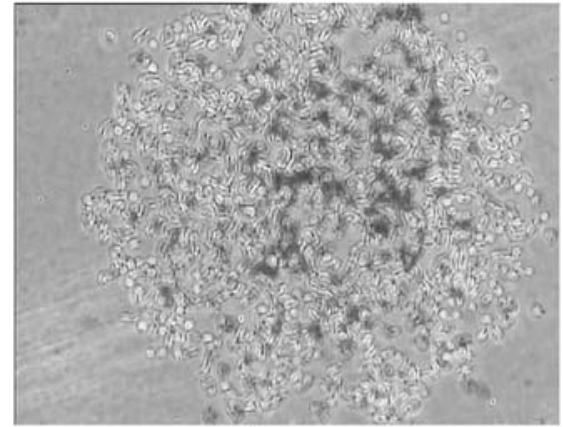

Figure 4. Image of clone under inverted microscope (stained by $1 \%$ crystal violet, $10 \times 10)$.

levels of Annexin V and PI (UR zone). We were also able to identify cells that had experienced mechanical injury during the experiment as having low levels of Annexin $\mathrm{V}$ and high levels of PI (UL zone). The spontaneous apoptotic rate of MCF-7 cells in the control was low. MCF-7 cells in the early apoptotic phase could be increased by $\mathrm{As}_{2} \mathrm{O}_{3}$. ${ }^{89} \mathrm{SrCl}_{2}$ increased the percentage of dead MCF-7 cells and increased the number of cells in the late apoptotic phase from $(2.1 \pm 0.7 \%)$ in the control to $(20.5 \pm 4.3 \%)$ in the $4 \mathrm{~Gy}$ ${ }^{89} \mathrm{SrCl}_{2}$ group. There was only a limited effect in the early apoptotic phase. In the combination groups, cells in both the early and late apoptotic phases as well as dead cells were all significantly increased. The rate of cells in the early apoptotic phase increased from $(6.7 \pm 1.8 \%)$ in the $4 \mathrm{~Gy}{ }^{89} \mathrm{SrCl}_{2}$ group to (32.6 $4.5 \%)$ in the $2 \mu \mathrm{M} \mathrm{As}_{2} \mathrm{O}_{3}$ and $4 \mathrm{~Gy}{ }^{89} \mathrm{SrCl}_{2}$ group $(\mathrm{P}<0.01)$. The number of cells in the late apoptotic phase and dead cell groups increased from $(20.5 \pm 4.3 \%)$ in the $4 \mathrm{~Gy}^{89} \mathrm{SrCl}_{2}$ group to $(25.7 \pm 6.2 \%)$ in the $2 \mu \mathrm{M} \mathrm{As}_{2} \mathrm{O}_{3}$ and $4 \mathrm{~Gy}{ }^{89} \mathrm{SrCl}_{2}$ group $(\mathrm{P}<0.05)$ (Fig. 5, Table II). 
Table I. The distribution of MCF-7 cell cycle after exposure to $\mathrm{As}_{2} \mathrm{O}_{3}$ and ${ }^{89} \mathrm{SrCl}_{2}($ mean $\pm \mathrm{SD}, \mathrm{n}=6$ ).

\begin{tabular}{|c|c|c|c|}
\hline Group & $\mathrm{G}_{0} / \mathrm{G}_{1}(\%)$ & $\mathrm{S}(\%)$ & $\mathrm{G}_{2} / \mathrm{M}(\%)$ \\
\hline Control & $65.6 \pm 10.6$ & $25.0 \pm 4.8$ & $9.4 \pm 5.3$ \\
\hline $1 \mu \mathrm{M} \mathrm{As}_{2} \mathrm{O}_{3}$ & $60.9 \pm 8.4$ & $23.6 \pm 6.0$ & $15.5 \pm 4.7^{\mathrm{a}}$ \\
\hline $2 \mu \mathrm{M} \mathrm{As}_{2} \mathrm{O}_{3}$ & $55.9 \pm 6.6$ & $25.8 \pm 6.5$ & $18.3 \pm 5.9^{\mathrm{a}}$ \\
\hline $1 \mathrm{~Gy}^{89} \mathrm{SrCl}_{2}$ & $64.2 \pm 7.8$ & $21.8 \pm 5.4$ & $14.0 \pm 5.1^{\mathrm{a}}$ \\
\hline $2 \mathrm{~Gy}{ }^{89} \mathrm{SrCl}_{2}$ & $59.1 \pm 6.8$ & $19.5 \pm 4.9$ & $21.4 \pm 6.1^{\mathrm{b}}$ \\
\hline $4 \mathrm{~Gy}{ }^{89} \mathrm{SrCl}_{2}$ & $55.5 \pm 7.0$ & $16.5 \pm 5.4$ & $28.0 \pm 6.7^{\mathrm{b}}$ \\
\hline $1 \mu \mathrm{M} \mathrm{As}_{2} \mathrm{O}_{3}+1 \mathrm{~Gy}{ }^{89} \mathrm{SrCl}_{2}$ & $59.7 \pm 8.3$ & $20.7 \pm 5.3$ & $19.6 \pm 5.7^{c}$ \\
\hline $1 \mu \mathrm{M} \mathrm{As}_{2} \mathrm{O}_{3}+2 \mathrm{~Gy}{ }^{89} \mathrm{SrCl}_{2}$ & $54.9 \pm 9.9$ & $16.4 \pm 7.1$ & $28.7 \pm 7.9^{c}$ \\
\hline $1 \mu \mathrm{M} \mathrm{As}_{2} \mathrm{O}_{3}+4 \mathrm{~Gy}{ }^{89} \mathrm{SrCl}_{2}$ & $52.6 \pm 7.5$ & $9.9 \pm 2.1^{\mathrm{c}}$ & $37.5 \pm 8.7^{\mathrm{c}}$ \\
\hline $2 \mu \mathrm{M} \mathrm{As}_{2} \mathrm{O}_{3}+1 \mathrm{~Gy}^{89} \mathrm{SrCl}_{2}$ & $57.9 \pm 11.6$ & $18.6 \pm 6.2$ & $23.5 \pm 5.3^{c}$ \\
\hline $2 \mu \mathrm{M} \mathrm{As}_{2} \mathrm{O}_{3}+2 \mathrm{~Gy}^{89} \mathrm{SrCl}_{2}$ & $52.7 \pm 8.1$ & $10.5 \pm 5.2^{\mathrm{d}}$ & $36.8 \pm 8.1^{\mathrm{d}}$ \\
\hline $2 \mu \mathrm{M} \mathrm{As}_{2} \mathrm{O}_{3}+4 \mathrm{~Gy}^{89} \mathrm{SrCl}_{2}$ & $49.0 \pm 7.4$ & $5.2 \pm 4.1^{\mathrm{d}}$ & $45.8 \pm 9.0^{\mathrm{d}}$ \\
\hline
\end{tabular}

Compared with control, ${ }^{\mathrm{a}}<0.05,{ }^{\mathrm{b}} \mathrm{P}<0.01$; compared with the ${ }^{89} \mathrm{SrCl}_{2}$ group, ${ }^{\mathrm{c}} \mathrm{P}<0.05,{ }^{\mathrm{d}} \mathrm{P}<0.01$.

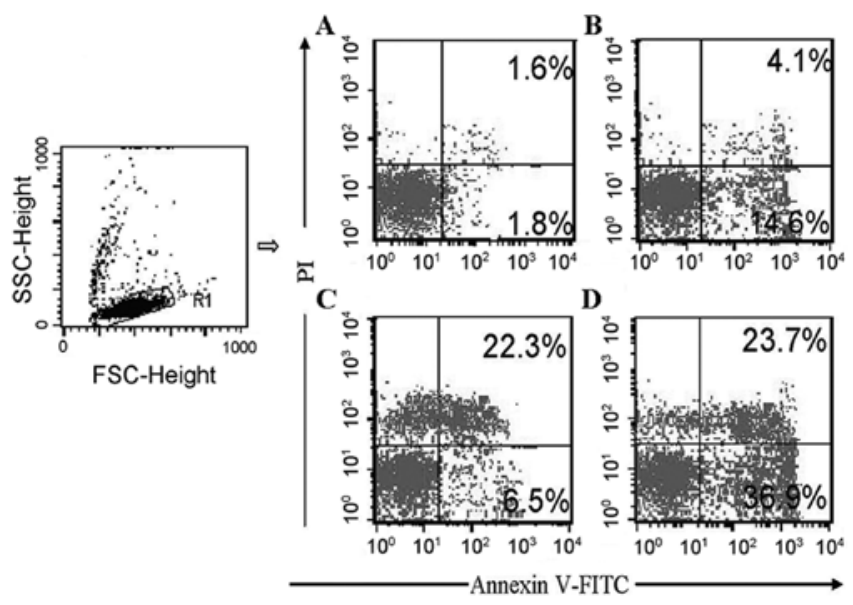

Figure 5. Flow cytometry picture of apoptotic MCF-7 cells in different groups. (A) Control. (B) $2 \mu \mathrm{M} \mathrm{As}_{2} \mathrm{O}_{3}$ group. (C) $4 \mathrm{~Gy}^{89} \mathrm{SrCl}_{2}$ group. (D) Combination group.

Effects of $\mathrm{As}_{2} \mathrm{O}_{3}$ and ${ }^{89} \mathrm{SrCl}_{2}$ on the expression of $\mathrm{Bcl}-2$ and $\mathrm{Bax}$ mRNA in MCF-7 cells. The expression of Bcl-2 mRNA was lower in the $2 \mu \mathrm{M} \mathrm{As}_{2} \mathrm{O}_{3}$ group and the $4 \mathrm{~Gy}^{89} \mathrm{SrCl}_{2}$ group, compared to control. However, expression of Bax mRNA was unchanged by treatment (Fig. 6).

Data was analysed by Smart view image software, and the relative values (the ratio of the sample intensity to the intensity of GAPDH) of expression of Bcl-2 mRNA in the 4 Gy ${ }^{89} \mathrm{SrCl}_{2}$ group and in the combination group were $(27.25 \pm 3.56 \%)$ and $(11.47 \pm 2.32 \%)(\mathrm{P}<0.05)$, respectively. There were no differences in Bax mRNA ( $\mathrm{P}>0.05)$. Despite this, the ratio of $\mathrm{Bcl}-2 / \mathrm{Bax}$ was significantly altered compared to control $(\mathrm{P}<0.05)$. Thus, $\mathrm{As}_{2} \mathrm{O}_{3}$ represses Bcl-2 mRNA expression caused by ${ }^{89} \mathrm{SrCl}_{2}$ without affecting the expression of Bax mRNA (Fig. 6, Table III).

Effects of $\mathrm{As}_{2} \mathrm{O}_{3}$ and ${ }^{89} \mathrm{SrCl}_{2}$ on the expression of $\mathrm{Bcl}-2$ and Bax proteins in MCF-7 cells. Bcl-2 and Bax proteins were
Table II. The apoptosis of MCF-7 cells exposed to $\mathrm{As}_{2} \mathrm{O}_{3}$ and ${ }^{89} \mathrm{SrCl}_{2}$ (mean $\left.\pm \mathrm{SD}, \mathrm{n}=6\right)$.

\begin{tabular}{lcc}
\hline Group & $\begin{array}{c}\text { Early } \\
\text { apoptotic } \\
\text { cells (\%) }\end{array}$ & $\begin{array}{c}\text { Dead and } \\
\text { late apototic } \\
\text { cells (\%) }\end{array}$ \\
\hline Control & $1.4 \pm 0.6$ & $2.1 \pm 0.7$ \\
$1 \mu \mathrm{M} \mathrm{As}{ }_{2} \mathrm{O}_{3}$ & $8.6 \pm 2.1^{\mathrm{a}}$ & $3.7 \pm 1.4$ \\
$2 \mu \mathrm{M} \mathrm{As}_{2} \mathrm{O}_{3}$ & $13.9 \pm 2.5^{\mathrm{a}}$ & $4.2 \pm 0.9$ \\
$1 \mathrm{~Gy}^{89} \mathrm{SrCl}_{2}$ & $3.1 \pm 0.5$ & $6.3 \pm 1.4^{\mathrm{a}}$ \\
$2 \mathrm{~Gy}^{89} \mathrm{SrCl}_{2}$ & $5.1 \pm 1.1$ & $9.3 \pm 0.8^{\mathrm{a}}$ \\
$4 \mathrm{~Gy}^{89} \mathrm{SrCl}_{2}$ & $6.7 \pm 1.8$ & $20.5 \pm 4.3^{\mathrm{a}}$ \\
$1 \mu \mathrm{M} \mathrm{As}_{2} \mathrm{O}_{3}+1 \mathrm{~Gy}{ }^{89} \mathrm{SrCl}_{2}$ & $8.8 \pm 0.9$ & $9.2 \pm 1.0^{\mathrm{d}}$ \\
$1 \mu \mathrm{M} \mathrm{As}_{2} \mathrm{O}_{3}+2 \mathrm{~Gy}{ }^{89} \mathrm{SrCl}_{2}$ & $13.1 \pm 2.6^{\mathrm{b}}$ & $14.9 \pm 2.3^{\mathrm{d}}$ \\
$1 \mu \mathrm{M} \mathrm{As}_{2} \mathrm{O}_{3}+4 \mathrm{~Gy}{ }^{89} \mathrm{SrCl}_{2}$ & $14.5 \pm 3.8^{\mathrm{b}}$ & $23.3 \pm 4.0$ \\
$2 \mu \mathrm{M} \mathrm{As}_{2} \mathrm{O}_{3}+1 \mathrm{~Gy}{ }^{89} \mathrm{SrCl}_{2}$ & $19.2 \pm 5.2^{\mathrm{c}}$ & $9.6 \pm 2.4^{\mathrm{d}}$ \\
$2 \mu \mathrm{M} \mathrm{As}_{2} \mathrm{O}_{3}+2 \mathrm{~Gy}{ }^{89} \mathrm{SrCl}_{2}$ & $23.7 \pm 5.6^{\mathrm{b}}$ & $17.3 \pm 3.1^{\mathrm{d}}$ \\
$2 \mu \mathrm{M} \mathrm{As}_{2} \mathrm{O}_{3}+4 \mathrm{~Gy}{ }^{89} \mathrm{SrCl}_{2}$ & $32.6 \pm 4.5^{\mathrm{b}}$ & $25.7 \pm 6.2^{\mathrm{e}}$ \\
\hline
\end{tabular}

Compared with control, ${ }^{\mathrm{a}}<0.01$; compared with the $\mathrm{As}_{2} \mathrm{O}_{3}$ group, ${ }^{\mathrm{b}} \mathrm{P}<0.01,{ }^{\mathrm{C}} \mathrm{P}<0.05$; compared with the ${ }^{89} \mathrm{SrCl}_{2}$ group, ${ }^{\mathrm{d}} \mathrm{P}<0.01,{ }^{\mathrm{e}} \mathrm{P}<0.05$.

both expressed in all MCF-7 control cells. Bcl-2 protein levels decreased in the $2 \mu \mathrm{M} \mathrm{As} \mathrm{O}_{3}$, the $4 \mathrm{~Gy}^{89} \mathrm{SrCl}_{2}$ and the combination group. However, Bax protein was unchanged by treatment. The relative expression of $\mathrm{Bcl}-2$ protein in the combination group was less than that in the $4 \mathrm{~Gy}{ }^{89} \mathrm{SrCl}_{2}$ group $(\mathrm{P}<0.05)$. There was no significant difference between the relative expression of Bax protein in each group $(\mathrm{P}>0.05)$ when analyzed by Smart view image software. It showed that $\mathrm{As}_{2} \mathrm{O}_{3}$ can inhibit the expression of $\mathrm{Bcl}-2$ protein, without evident effects on the expression of Bax protein. Thus, the ratio of $\mathrm{Bcl}-2 / \mathrm{Bax}$ was decreased, which is in accordance with the effects of ${ }^{89} \mathrm{SrCl}_{2}$ (Fig. 7, Table IV). 


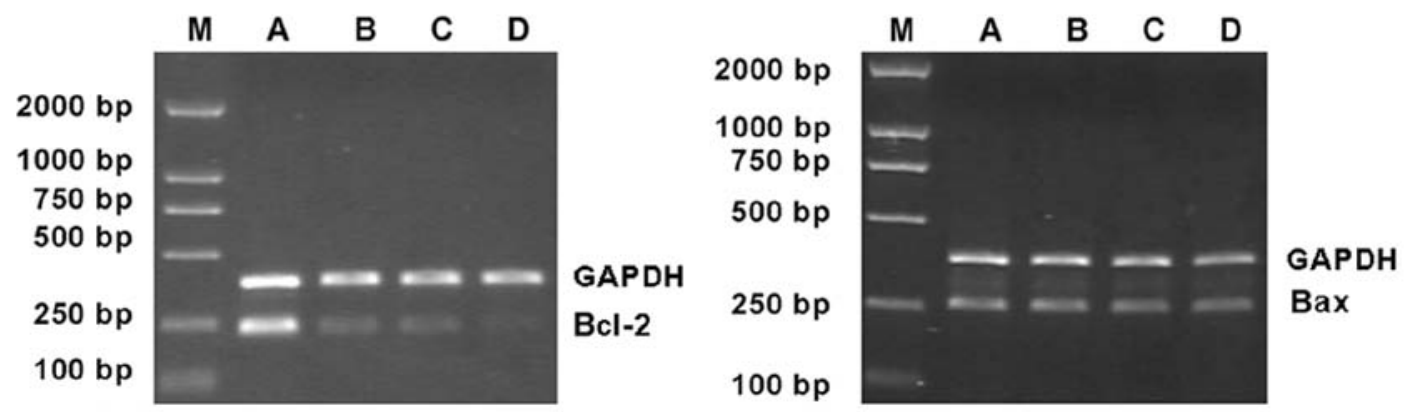

Figure 6. Expression of Bcl-2 and Bax mRNA in MCF-7 cells in different groups. M, DNA marker. (A) Control. (B) $2 \mu \mathrm{M} \mathrm{As}_{2} \mathrm{O}_{3}$ group. (C) $4 \mathrm{~Gy}^{89} \mathrm{SrCl}_{2}$ group. (D) Combination group.

Table III. Comparison between the expressions of Bcl-2 and Bax mRNA in MCF-7 cells in different groups (\%, mean $\pm \mathrm{SD}, \mathrm{n}=3)$.

\begin{tabular}{lccl}
\hline Group & Bcl-2 & Bax & Bcl-2/Bax \\
\hline Control & $93.41 \pm 8.79$ & $49.36 \pm 6.23$ & $1.84 \pm 0.21$ \\
$2 \mu \mathrm{M} \mathrm{As}_{2} \mathrm{O}_{3}$ & $46.52 \pm 5.24^{\mathrm{a}}$ & $52.14 \pm 5.71^{\mathrm{c}}$ & $0.93 \pm 0.12^{\mathrm{a}}$ \\
$4 \mathrm{~Gy}^{89} \mathrm{SrCl}_{2}$ & $27.25 \pm 3.56^{\mathrm{a}}$ & $47.73 \pm 5.62^{\mathrm{c}}$ & $0.53 \pm 0.07^{\mathrm{a}}$ \\
Combination & $11.47 \pm 2.32^{\mathrm{b}, \mathrm{d}}$ & $49.67 \pm 6.07^{\mathrm{c}, \mathrm{e}}$ & $0.20 \pm 0.04^{\mathrm{b}, \mathrm{d}}$ \\
group & & & \\
\hline
\end{tabular}

Compared with control, ${ }^{\mathrm{a}} \mathrm{P}<0.05,{ }^{\mathrm{b}} \mathrm{P}<0.01,{ }^{\mathrm{c}} \mathrm{P}>0.05$; compared with those in the $4 \mathrm{~Gy}{ }^{89} \mathrm{SrCl}_{2}$ group, ${ }^{\mathrm{d}} \mathrm{P}<0.05,{ }^{\mathrm{e}} \mathrm{P}>0.05$.

Table IV. Comparison between the expressions of Bcl-2 and Bax proteins in MCF-7 cells (\%, mean $\pm \mathrm{SD}, \mathrm{n}=3)$.

\begin{tabular}{lccl}
\hline Group & Bcl-2 & Bax & Bcl-2/Bax \\
\hline Control & $86.52 \pm 9.23$ & $42.53 \pm 5.23$ & $1.98 \pm 0.23$ \\
$2 \mu \mathrm{M} \mathrm{As}_{2} \mathrm{O}_{3}$ & $41.35 \pm 6.41^{\mathrm{a}}$ & $45.94 \pm 5.92^{\mathrm{c}}$ & $0.97 \pm 0.16^{\mathrm{a}}$ \\
$4 \mathrm{~Gy}^{89} \mathrm{SrCl}_{2}$ & $33.58 \pm 4.54^{\mathrm{a}}$ & $49.68 \pm 4.85^{\mathrm{c}}$ & $0.64 \pm 0.09^{\mathrm{a}}$ \\
Combination & $12.72 \pm 2.16^{\mathrm{b}, \mathrm{d}}$ & $52.15 \pm 6.34^{\mathrm{c}, \mathrm{e}}$ & $0.22 \pm 0.05^{\mathrm{b}, \mathrm{d}}$ \\
group & & & \\
\hline
\end{tabular}

Compared with control, ${ }^{\mathrm{a}} \mathrm{P}<0.05$, ${ }^{\mathrm{b}} \mathrm{P}<0.01,{ }^{\mathrm{c}} \mathrm{P}>0.05$; compared with those in the $4 \mathrm{~Gy}{ }^{89} \mathrm{SrCl}_{2}$ group, ${ }^{\mathrm{d}} \mathrm{P}<0.05,{ }^{\mathrm{e}} \mathrm{P}>0.05$.

\section{Discussion}

Breast cancer is one of the most common types of cancer in women and it is often associated with bone metastases $(2,3)$. Currently, the common approach for the treatment of bone metastasis is external beam radiation therapy. While this method is relatively effective for a single large metastasis, it is quite poor for the treatment of multiple lesions. Systemic medication (analgesic drug therapy and chemotherapy) has some advantages for patients with multiple bone metastases, but there are other toxic side-effects associated with such therapies. Systemic radionuclide therapy has drawn much attention in the clinic. It is a relatively simple and economical procedure that effectively relieves pain and can target multiple bone metastases with few side-effects.

${ }^{89} \mathrm{SrCl}_{2}$ has been widely and successfully used for the treatment of bone metastases (15-17). Similar to calcium, ${ }^{89} \mathrm{Sr}$ is a nuclide that is commonly found in bone. It is estimated that $30-80 \%$ of intravenously injected ${ }^{89} \mathrm{Sr}$ will aggregate in the bone, especially at sites of active bone formation. Thus, its accumulation within bone metastases is about 2-25 times higher than it is in normal bone (18). The physical half-life of ${ }^{89} \mathrm{Sr}$ is 50.56 days, and its biological half-life in normal bone is 14 days. However, $12-90 \%$ of ${ }^{89} \mathrm{Sr}$ is still retained within bone metastases 3 months after ${ }^{89} \mathrm{Sr}$ injection. The longterm accumulation of ${ }^{89} \mathrm{Sr}$ within the bone metastatic lesion is a significant advantage for ${ }^{89} \mathrm{Sr}$ to treat bone metastases. Physically, ${ }^{89} \mathrm{Sr}$ emits pure $\beta$-rays with an average energy of $1.46 \mathrm{MeV}$, producing an average range in the bone of only $3 \mathrm{~mm}$. Therefore, ${ }^{89} \mathrm{Sr}$ can effectively kill tumor cells while limiting its effect on the surrounding bone. This results in the shrinkage or elimination of bone metastases and relief of bone pain. Nevertheless, there are still some patients who do not respond due to radioresistance of tumor cells $(19,20)$. Thus, searching for safe and effective radiation sensitizers to improve the efficacy of radiation therapy has become a hot topic in radiation biology.

In recent years, arsenic and some Chinese herbs have been found to have radiosensitizing effects. $\mathrm{As}_{2} \mathrm{O}_{3}$ is the main component of Chinese medicine arsenic, which was first used for the treatment of patients with APL; in these patients, the treatment had a beneficial effect. In addition, other studies (21-24) have shown that $\mathrm{As}_{2} \mathrm{O}_{3}$ can induce tumor cell apoptosis and inhibit the growth of some solid tumors, including esophageal and liver cancers. This effect is partly due to regulation of cell cycle progression, induction of apoptosis and differentiation, blockage of tumor cell sub-lethal DNA damage repair, reduction of telomerase activity and glutathione content in tumor cells, and inhibition of angiogenesis (25). Such mechanisms can also enhance the radiosensitivity of tumor cells (26), providing the theoretical basis for the clinical application of $\mathrm{As}_{2} \mathrm{O}_{3}$ as a radiation sensitizer. In this study, we demonstrated that $\mathrm{As}_{2} \mathrm{O}_{3}$ dose-dependently inhibits the proliferation of MCF-7 cells in vitro (with $\mathrm{IC}_{50}$ at $11.7 \mu \mathrm{M}$, Fig. 1). In our radiosensitizing experiment, we found that there were no significant morphological changes of MCF-7 cells treated with low doses of $\mathrm{As}_{2} \mathrm{O}_{3}$, but obvious changes were observed for the cells exposed to ${ }^{89} \mathrm{SrCl}_{2}$ for $48 \mathrm{~h}$, which was accompanied 


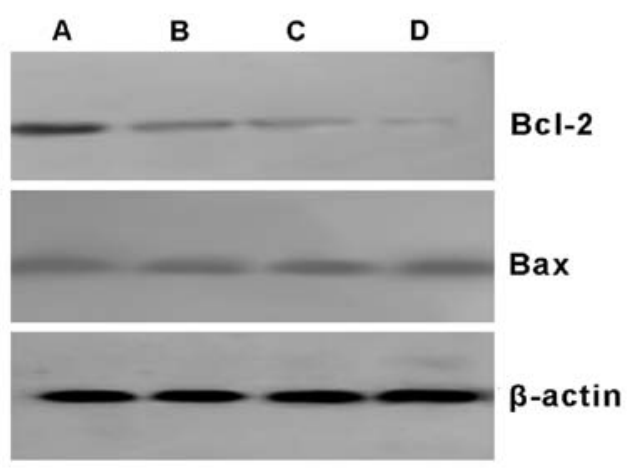

Figure 7. Western blot detection of expression of Bcl-2 and Bax proteins in MCF-7 cells. (A) Control. (B) $2 \mu \mathrm{M} \mathrm{As}_{2} \mathrm{O}_{3}$ group. (C) $4 \mathrm{~Gy}{ }^{89} \mathrm{SrCl}_{2}$ group. (D) Combination group.

by cell growth inhibition. When cells were treated with the combination of $\mathrm{As}_{2} \mathrm{O}_{3}$ and ${ }^{89} \mathrm{SrCl}_{2}$ treatment, significant cell death, apoptosis and growth inhibition were observed.

Radiation dose-survival curves reflect irradiated cell survival in vitro and accurately determine proliferation and cell death. The parameters $\mathrm{D}_{0}, \mathrm{D}_{\mathrm{q}}$ and $\mathrm{N}$ can be calculated from the radiation dose-survival curve. The $\mathrm{D}_{0}$ is the average lethal dose needed to cause cell death; this reflects the degree of cell sensitivity to radiation. The greater the $\mathrm{D}_{0}$ value, the lower the cell sensitivity to radiation. The threshold dose $\mathrm{D}_{\mathrm{q}}$ value reflects the repair capacity of cells to sublethal damage and negatively correlates with radiation sensitivity. The $\mathrm{N}$ is the extrapolation number, reflecting the number of radiationsensitive areas within the cell or required number of target hits. Any two of the three parameters can be used to reflect the extent of radiation sensitivity of cells (14).

In our study, we found that compared to ${ }^{89} \mathrm{SrCl}_{2}$ radiation alone, the addition of $\mathrm{As}_{2} \mathrm{O}_{3}$ significantly decreased the $\mathrm{D}_{0}$ and $\mathrm{D}_{\mathrm{q}}$ values of MCF-7 cells $(\mathrm{P}<0.05)$. This translated into radiosensitization ratios of 1.25 and 1.79 , respectively, indicating that pretreatment with $\mathrm{As}_{2} \mathrm{O}_{3}$ significantly reduces the average lethal dose of MCF-7 cells to ${ }^{89} \mathrm{SrCl}_{2}$ irradiation. Thus, $\mathrm{As}_{2} \mathrm{O}_{3}$ significantly increases the radiosensitivity of MCF-7 cells to ${ }^{89} \mathrm{SrCl}_{2}$ irradiation in a dose-dependent manner.

Uncontrolled cell proliferation is one of the prominent features of cancer cells, which may result from deregulated cell cycle control. There are a few key phase regulatory sites that play key roles in the regulation of cell cycle progression. Of these, the regulatory sites at the $\mathrm{G}_{1} / \mathrm{S}$ and $\mathrm{G}_{2} / \mathrm{M}$ phases are the most important $(27,28)$. Many anticancer drugs cause cell cycle arrest in the $\mathrm{G}_{1} / \mathrm{S}$ or $\mathrm{G}_{2} / \mathrm{M}$ phases to inhibit tumor proliferation (29). The radiosensitivity of tumor cells is closely related to both their capacity to repair DNA and their phase in the cell cycle. Cells in the $\mathrm{G}_{2} / \mathrm{M}$ phase are most sensitive to radiation; cells in early $S$ phase and $G_{1}$ phase are moderately sensitive, and cells in late $\mathrm{S}$ phase are least sensitive to radiation (30). Therefore, an important consideration to improving radiosensitivity and radiotherapy efficacy involves promoting tumor cells to enter the cell cycle but to remain in the $\mathrm{G}_{2} / \mathrm{M}$ phase. In our study, we found that ${ }^{89} \mathrm{SrCl}_{2}$ or $\mathrm{As}_{2} \mathrm{O}_{3}$ treatment dose-dependently increased the percentage of MCF-7 cells in $\mathrm{G}_{2} / \mathrm{M}$ phase, but there was no significant effect on $\mathrm{G}_{0} / \mathrm{G}_{1}$ phase. This suggested that ${ }^{89} \mathrm{SrCl}_{2}$ or $\mathrm{As}_{2} \mathrm{O}_{3}$ treatment could cause
MCF-7 cells to arrest in $\mathrm{G}_{2} / \mathrm{M}$ phase. Compared to ${ }^{89} \mathrm{SrCl}_{2}$ treatment alone, addition of $\mathrm{As}_{2} \mathrm{O}_{3}$ significantly increased the percentage of cells in $\mathrm{G}_{2} / \mathrm{M}$ phase (and decreased in $\mathrm{G}_{0} / \mathrm{G}_{1}$ phase). The percentage of cells in radioresistant $S$ phase reached its lowest proportion. These results suggest that the $\mathrm{G}_{2} / \mathrm{M}$ phase arrest and decrease of cell number in $\mathrm{S}$ phase might be one mechanism by which $\mathrm{As}_{2} \mathrm{O}_{3}$ sensitizes MCF-7 cells to ${ }^{89} \mathrm{SrCl}_{2}$ irradiation. These results are consistent with previous studies (31-33) showing that $\mathrm{As}_{2} \mathrm{O}_{3}$ can upregulate cyclin B, CDK-1 and p21, but downregulate CDK-6, CDC-2 and cyclin A expression. This correlated with an effect on $\mathrm{G}_{2} / \mathrm{M}$ cell cycle arrest.

Radiation-induced apoptosis is an important mechanism to kill tumor cells. Thus, inducing apoptosis in tumor cells has become a new strategy in radiation oncology. Apoptosis is also the common pathway by which many antitumor drugs exert their effects. FCM is a common method for studying apoptosis, and it can sensitively and accurately distinguish between early and late phases of apoptotic cells via double staining for Annexin V/ PI (34). In the present study, we found that ${ }^{89} \mathrm{SrCl}_{2}$ irradiation significantly induced late phase apoptosis and cell death but had little effect on early phase apoptosis of MCF-7 cells. However, addition of $\mathrm{As}_{2} \mathrm{O}_{3}$ significantly induced not only late phase apoptosis and cell death but also early phase apoptosis of MCF-7 cells ( $\mathrm{P}<0.01 ; \mathrm{P}<0.05$ vs. ${ }^{89} \mathrm{SrCl}_{2}$ treatment only). These results suggest that increasing the sensitivity of MCF-7 cells to ${ }^{89} \mathrm{SrCl}_{2}$-induced apoptosis might be one of the mechanisms by which $\mathrm{As}_{2} \mathrm{O}_{3}$ sensitizes cells to ${ }^{89} \mathrm{SrCl}_{2}$ irradiation.

Numerous factors affect the response of tumor cells to radiation, including the ability to repair DNA double strand breaks, transmembrane signal transduction and apoptosisrelated gene expression (35). Previous studies (36-40) showed that Bcl-2 and Bax play significant roles in the regulation of apoptosis after irradiation. For example, it has been reported that knockdown of $\mathrm{Bcl}-2$ expression significantly sensitized human PC-3 prostate cancer cells to irradiation (38). In this study, we found that the expression of Bcl-2 and Bax at both the mRNA and protein levels can be detected in MCF-7 cells without any treatment. Treatment with $2 \mu \mathrm{M} \mathrm{As}_{2} \mathrm{O}_{3}$ or $4 \mathrm{~Gy}$ ${ }^{89} \mathrm{SrCl}_{2}$ irradiation reduced the antiapoptotic gene $\mathrm{Bcl}-2$ at both the mRNA and protein levels. This reduction was more significant in the combination group ( $\mathrm{P}<0.05$ vs. $4 \mathrm{~Gy}^{89} \mathrm{SrCl}_{2}$ group). We did not detect significant changes in Bax expression, but the overall $\mathrm{Bcl}-2 / \mathrm{Bax}$ ration did decrease in the individual experimental groups compared to control. This suggests that the radiosensitizing effect of $\mathrm{As}_{2} \mathrm{O}_{3}$ might be due to inhibition of $\mathrm{Bcl}-2$ expression and subsequent reduction of the ratio of Bcl-2/Bax, which increases the sensitivity of MCF-7 cells to ${ }^{89} \mathrm{SrCl}_{2}$ irradiation. Another study showed that with the reduction of the Bcl-2/Bax ratio, the formation of Bax homodimers increases, resulting in an increase of the permeability of the mitochondrial membrane in tumor cells (41). This leads to the release of cytochrome $c$, activation of downstream signaling pathways, and activation of caspase family members and apoptosis. Kumagai et al (42) have consistently found that $\mathrm{As}_{2} \mathrm{O}_{3}$-induced apoptosis is correlated with downregulation of Bcl-2 and Bcl-xL expressions in NB4 cells.

In summary, we found that low doses of $\mathrm{As}_{2} \mathrm{O}_{3}$ (below 20\% of the $\mathrm{IC}_{50}$ ) significantly enhance the sensitivity of MCF-7 cells to ${ }^{89} \mathrm{SrCl}_{2} \beta$-ray irradiation in vitro, which is, at least in 
part, through inducing $\mathrm{G}_{2} / \mathrm{M}$ cell cycle arrest, downregulating Bcl-2 gene expression, and reducing the ratio of $\mathrm{Bcl}-2 / \mathrm{Bax}$. Consequently, the overall effect is an increase in cell apoptosis. Further understanding of the underlying molecular mechanisms and exploring the possibility of $\mathrm{As}_{2} \mathrm{O}_{3}$ radiosensitization in vivo may have significant clinical implications and provide experimental evidence to improve the radionuclide therapeutic efficacy on malignant bone metastasis.

In conclusion, we demonstrated that $1-2 \mu \mathrm{M}$ of $\mathrm{As}_{2} \mathrm{O}_{3}$ could increase the radiosensitivity of human breast cancer MCF-7 cell line by inducing $G_{2}$ phase delay. The lethal effect of ${ }^{89} \mathrm{SrCl}_{2}$ on MCF-7 cells thus was enhanced concomitantly with $\mathrm{As}_{2} \mathrm{O}_{3}$ pretreatment. The mechanism could be involved in the raising of the apoptosis rate of cells owing to the reduction of the $\mathrm{Bcl}-2 / \mathrm{Bax}$ rate.

\section{Acknowledgements}

This study was supported by the Anhui Province Natural Science Foundation (1208085MH162), Anhui Province Department of Education Fund (20101941, KJ2011Z162), Anhui Province Department of Health Medical Science Fund (2010C081) and the Key Laboratory Program of New Thin Solar Cell, Chinese Academy of Science (2010007). We also thank the experimental center of clinical laboratory diagnostics in Bengbu Medical College for providing us the MCF-7 cell line.

\section{References}

1. Parkin DM, Bray F, Ferlay $\mathbf{J}$ and Pisani P: Global cancer statistics, 2002. CA Cancer J Clin 55: 74-108, 2005.

2. Yang L, Parkin DM, Li L and Chen Y: Time trends in cancer mortality in China: 1987-1999. Int J Cancer 106: 771-783, 2003.

3. Baczyk M, Czepczynski R, Milecki P, Pisarek M, Oleksa R and Sowinski J: 89Sr versus 153Sm-EDTMP: comparison of treatment efficacy of painful bone metastases in prostate and breast carcinoma. Nucl Med Commun 28: 245-250, 2007.

4. Adams GE, Ahmed I, Sheldon PW and Stratford IJ: RSU 1069, a 2-nitroimidazole containing an alkylating group: high efficiency as a radio- and chemosensitizer in vitro and in vivo. Int $\mathbf{J}$ Radiat Oncol Biol Phys 10: 1653-1656, 1984.

5. Ni X, Zhang Y, Ribas J, et al: Prostate-targeted radiosensitization via aptamer-shRNA chimeras in human tumor xenografts. J Clin Invest 121: 2383-2390, 2011.

6. Baj G, Arnulfo A, Deaglio S, et al: Arsenic trioxide and breast cancer: analysis of the apoptotic, differentiative and immunomodulatory effects. Breast Cancer Res Treat 73: 61-73, 2002.

7. Li Y, Qu X, Qu J, et al: Arsenic trioxide induces apoptosis and $\mathrm{G} 2 / \mathrm{M}$ phase arrest by inducing Cbl to inhibit PI3K/Akt signaling and thereby regulate p53 activation. Cancer Lett 284: 208-215, 2009.

8. Siu KP, Chan JY and Fung KP: Effect of arsenic trioxide on human hepatocellular carcinoma HepG2 cells: inhibition of proliferation and induction of apoptosis. Life Sci 71: 275-285, 2002.

9. Ling YH, Jiang JD, Holland JF and Perez-Soler R: Arsenic trioxide produces polymerization of microtubules and mitotic arrest before apoptosis in human tumor cell lines. Mol Pharmacol 62: 529-538, 2002.

10. Davison K, Mann KK and Miller WH Jr: Arsenic trioxide: mechanisms of action. Semin Hematol 39: 3-7, 2002.

11. Ai Z, Lu W, Ton S, et al: Arsenic trioxide-mediated growth inhibition in gallbladder carcinoma cells via down-regulation of Cyclin D1 transcription mediated by Sp1 transcription factor. Biochem Biophys Res Commun 360: 684-689, 2007.

12. Lin LM, Li BX, Xiao JB, Lin DH and Yang BF: Synergistic effect of all-trans-retinoic acid and arsenic trioxide on growth inhibition and apoptosis in human hepatoma, breast cancer, and lung cancer cells in vitro. World J Gastroenterol 11: 5633-5637, 2005 .
13. Friesen C, Lubatschofski A, Kotzerke J, Buchmann I, Reske SN and Debatin KM: Beta-irradiation used for systemic radioimmunotherapy induces apoptosis and activates apoptosis pathways in leukaemia cells. Eur J Nucl Med Mol Imaging 30: 1251-1261, 2003.

14. Xia S, Yu S, Fu Q, et al: Inhibiting PI3K/Akt pathway increases DNA damage of cervical carcinoma HeLa cells by drug radiosensitization. J Huazhong Univ Sci Technolog Med Sci 30: 360-364, 2010.

15. Giammarile F, Mognetti T and Resche I: Bone pain palliation with strontium-89 in cancer patients with bone metastases. Q J Nucl Med 45: 78-83, 2001.

16. Falkmer U, Jarhult J, Wersall P and Cavallin-Stahl E: A systematic overview of radiation therapy effects in skeletal metastases. Acta Oncol 42: 620-633, 2003.

17. Gkialas I, Iordanidou L, Galanakis I and Giannopoulos S: The use of radioisotopes for palliation of metastatic bone pain. J BUON 13: 177-183, 2008 .

18. Finlay IG, Mason MD and Shelley M: Radioisotopes for the palliation of metastatic bone cancer: a systematic review. Lancet Oncol 6: 392-400, 2005.

19. Gunawardana DH, Lichtenstein M, Better N and Rosenthal M: Results of strontium- 89 therapy in patients with prostate cancer resistant to chemotherapy. Clin Nucl Med 29: 81-85, 2004.

20. Rasch-Isla Munoz A and Catano Catano JG: Usefulness of bonespecific alkaline phosphatase for bone metastases detection in prostate cancer. Arch Esp Urol 57: 693-698, 2004 (In Spanish).

21. Wetzler M, Brady MT, Tracy E, et al: Arsenic trioxide affects signal transducer and activator of transcription proteins through alteration of protein tyrosine kinase phosphorylation. Clin Cancer Res 12: 6817-6825, 2006.

22. Kang SH, Song JH, Kang HK, et al: Arsenic trioxide-induced apoptosis is independent of stress-responsive signaling pathways but sensitive to inhibition of inducible nitric oxide synthase in HepG2 cells. Exp Mol Med 35: 83-90, 2003.

23. Xiao YF, Liu SX, Wu DD, Chen X and Ren LF: Inhibitory effect of arsenic trioxide on angiogenesis and expression of vascular endothelial growth factor in gastric cancer. World J Gastroenterol 12: 5780-5786, 2006.

24. Shen ZY, Zhang Y, Chen JY, et al: Intratumoral injection of arsenic to enhance antitumor efficacy in human esophageal carcinoma cell xenografts. Oncol Rep 11: 155-159, 2004.

25. Shao QS, Ye ZY, Ling ZQ and Ke JJ: Cell cycle arrest and apoptotic cell death in cultured human gastric carcinoma cells mediated by arsenic trioxide. World J Gastroenterol 11: 3451-3456, 2005 .

26. Ning S and Knox SJ: Optimization of combination therapy of arsenic trioxide and fractionated radiotherapy for malignant glioma. Int J Radiat Oncol Biol Phys 65: 493-498, 2006.

27. Park WH, Seol JG, Kim ES, et al: Arsenic trioxide-mediated growth inhibition in MC/CAR myeloma cells via cell cycle arrest in association with induction of cyclin-dependent kinase inhibitor, p21, and apoptosis. Cancer Res 60: 3065-3071, 2000.

28. Sancar A, Lindsey-Boltz LA, Unsal-Kacmaz K and Linn S: Molecular mechanisms of mammalian DNA repair and the DNA damage checkpoints. Annu Rev Biochem 73: 39-85, 2004

29. Umemura S, Takekoshi S, Suzuki Y, Saitoh Y, Tokuda Y and Osamura RY: Estrogen receptor-negative and human epidermal growth factor receptor 2-negative breast cancer tissue have the highest Ki-67 labeling index and EGFR expression: gene amplification does not contribute to EGFR expression. Oncol Rep 14: 337-343, 2005.

30. Rupnow BA, Murtha AD, Alarcon RM, Giaccia AJ and Knox SJ: Direct evidence that apoptosis enhances tumor responses to fractionated radiotherapy. Cancer Res 58: 1779-1784, 1998.

31. Park JW, Choi YJ, Jang MA, et al: Arsenic trioxide induces G2/M growth arrest and apoptosis after caspase-3 activation and Bcl-2 phosphorylation in promonocytic U937 cells. Biochem Biophys Res Commun 286: 726-734, 2001.

32. Yih LH, Hsueh SW, Luu WS, Chiu TH and Lee TC: Arsenite induces prominent mitotic arrest via inhibition of G2 checkpoint activation in CGL-2 cells. Carcinogenesis 26: 53-63, 2005.

33. Dai J, Weinberg RS, Waxman S and Jing Y: Malignant cells can be sensitized to undergo growth inhibition and apoptosis by arsenic trioxide through modulation of the glutathione redox system. Blood 93: 268-277, 1999.

34. Middleton G, Cox SW, Korsmeyer S and Davies AM: Differences in Bcl-2- and Bax-independent function in regulating apoptosis in sensory neuron populations. Eur J Neurosci 12: $819-827,2000$ 
35. Li L, Story $M$ and Legerski RJ: Cellular responses to ionizing radiation damage. Int J Radiat Oncol Biol Phys 49: 1157-1162, 2001.

36. Gupta S, Yel L, Kim D, Kim C, Chiplunkar S and Gollapudi S: Arsenic trioxide induces apoptosis in peripheral blood $\mathrm{T}$ lymphocyte subsets by inducing oxidative stress: a role of Bcl-2. Mol Cancer Ther 2: 711-719, 2003.

37. Cory S, Huang DC and Adams JM: The Bcl-2 family: roles in cell survival and oncogenesis. Oncogene 22: 8590-8607, 2003.

38. Xu L, Yang D, Wang S, et al: (-)-Gossypol enhances response to radiation therapy and results in tumor regression of human prostate cancer. Mol Cancer Ther 4: 197-205, 2005.

39. Anai S, Goodison S, Shiverick K, Hirao Y, Brown BD and Rosser CJ: Knock-down of Bcl-2 by antisense oligodeoxynucleotides induces radiosensitization and inhibition of angiogenesis in human PC-3 prostate tumor xenografts. Mol Cancer Ther 6 : 101-111, 2007.
40. Shore GC and Viallet J: Modulating the Bcl-2 family of apoptosis suppressors for potential therapeutic benefit in cancer. Hematology Am Soc Hematol Educ Program, pp226-230, 2005.

41. Chou JJ, Li H, Salvesen GS, Yuan J and Wagner G: Solution structure of BID, an intracellular amplifier of apoptotic signaling. Cell 96: 615-624, 1999.

42. Kumagai T, Shih LY, Hughes SV, et al: 19-Nor-1,25(OH)2D2 (a novel, noncalcemic vitamin D analogue), combined with arsenic trioxide, has potent antitumor activity against myeloid leukemia. Cancer Res 65: 2488-2497, 2005. 